\title{
Molecular and pathological identification of maize genotypes having Wsm gene governing resistance against MDMV and MCDV
}

\author{
Shanjida Rahman, Md. Ashraful Haque, Upama Mondal and Lutful Hassan
}

Department of Genetics and Plant Breeding, Bangladesh Agricultural University, Mymensingh-2202, Bangladesh

\begin{tabular}{|c|c|}
\hline ARTICLE INFO & Abstract \\
\hline $\begin{array}{l}\text { Article history: } \\
\text { Received: } 25 \text { April } 2018 \\
\text { Accepted: } 10 \text { July } 2018\end{array}$ & \multirow{3}{*}{$\begin{array}{l}\text { Maize is seriously affected by different viruses like Maize Dwarf Mosaic Virus (MDMV) and Maize } \\
\text { Chlorotic Dwarf Virus (MCDV) throughout the world. In Bangladesh, no genotype has been identified yet } \\
\text { as a source of resistant gene against MDMV and MCDV. The study was carried out with the objective to } \\
\text { screen nine maize genotypes carrying Wsm gene using three sets of Single Sequence Repeat (SSR) } \\
\text { marker. Maize plants were inoculated with viruses. Symptoms were scored at } 7,10 \text { and } 14 \text { dpi (days post } \\
\text { inoculation) to calculate infection percentage and Area Under Disease Progress Curve (AUDPC). The } \\
\text { molecular result indicated that BHM-7, BHM-5, V-92, Uttaran and Duranta carried Wsm gene, but } \\
\text { according to pathological test, functional resistance was observed for only BHM-7, V-92 and Uttaran on } \\
\text { the basis of infection percentage and AUDPC score. BHM-7 (BARI Hybrid Maize 7) was noticed as the } \\
\text { best one for showing resistance against MDMV and carrying Wsm gene. No genotype was found to } \\
\text { govern resistance against MCDV. }\end{array}$} \\
\hline $\begin{array}{l}\text { Keywords: } \\
\text { Maize, resistance, } \\
\text { MDMV, MCDV }\end{array}$ & \\
\hline $\begin{array}{l}\text { Correspondence: } \\
\text { Md. Ashraful Haque } \\
\text { (ashraf_gpb2000@yahoo.com) }\end{array}$ & \\
\hline
\end{tabular}

\section{Introduction}

Maize (Zea mays) is an important crop throughout the world including Bangladesh which occupies a large portion of world economy (Gong et al., 2015; Ranum et al., 2014; Ahmed, 2013; Roper, 2013; Moniruzzaman et al., 2009; Paliwal et al., 2000; Dowswell et al., 1996). But each year yield decreases due to occurrence of different diseases. Maize dwarf mosaic disease is one of them which is caused by a series of viruses including Maize dwarf mosaic virus (MDMV), Maize chlorotic dwarf virus (MCDV), Sugarcane mosaic virus (SCMV), Johnsongrass mosaic virus (JGMV), Sorghum mosaic virus (SrMV), Zea mosaic virus (ZeMV) and Pennisetum mosaic virus (PenMV) (Zambrano et al., 2014, Stewart et al., 2012; Stewart et al., 2013). All of them except MCDV are classified as the "sugarcane mosaic subgroup" of the virus genus Potyvirus, under the family Potyviridae (Balarabe et al., 2014, Haider et al., 2011, Mohammadi and Hajieghrari 2009, Shukla et al., 1992). The genus Potyvirus is one of the largest virus genera which currently includes 111 confirmed species; a further 86 tentative species have been noted by the International Committee on Taxonomy of Viruses (ICTV) (Zheng et al., 2010; Zheng et al., 2008; Fauquet et al., 2005). Potyviruses are economically important groups of plant viruses that pose a dangerous threat to crops around the world (Dujovny et al., 2000; Moriones and Luis-Arteaga, 2000; Inoue-Nagata et al., 2002; Larsen et al., 2003).

MDMV is one of the most important plant pathogenic viruses for corn that is distributed throughout the southern USA (Pataky et al., 1990), Europe (Tosic et al., 1977), Asia (Klein et al., 1973) and Australia (Penrose,
1974). The virus is transmitted mechanically by in a non-persistent manner by a broad range of aphids (Ford et al., 2004). The diagnostic symptoms of MDMV are white mosaic, chlorosis and streak on young leaves which result reduced plant biomass (Lapierre and Signoret, 2004). Maize chlorotic dwarf virus (MCDV) is another destructive virus belongs to the genus Waikavirus of the family Sequiviridae which is an economically devastating maize disease throughout the world especially in the Southeastern United States. It is considered to be the second major corn virus disease in the USA (Knoke and Louie, 1981). The virus is transmitted by leafhopper in a semi-persistent manner (Reddick et al., 1997; Gingery et al., 1981). ). Symptoms appeared on maize due to MCDV are chlorotic spots, stunting, severe stunting, leaf discoloration (reddening and yellowing) and leaf-tearing (Bradfute et al., 1972).

Generally, viral diseases are controlled by removal of virus reservoirs and vector but that may reduce biodiversity. Again, chemical control of vectors is not possible due to non-persistent mode of virus transmission (Adams et al., 2005; Ingvardsen et al., 2010). So, cultivation of resistant maize varieties is the most effective way to control virus infections. A number of maize inbred lines and landraces have been identified showing resistance to MDMV, SCMV, JGMV and SrMV (Kuntze et al., 1995, Redinbaugh and Pratt, 2008). The inbred line Pa405 is one of them which is resistant due to presence of three dominant genes referred as Wsm1, Wsm2 and Wsm3 that confer resistance to another member of the family Potyviridae and genus Tritimovirus, Wheat streak mosaic virus 
(WSMV) (McMullen et al., 1994; Mikel et al., 1984, Redinbaugh and Pratt, 2008, Stewart et al., 2013a). Wsm1 is located on the short arm of chromosome 6, Wsm2 near the centromere on chromosome 3 and Wsm3 on the long arm of chromosome 10 (McMullen et al., 1994; Redinbaugh and Pratt, 2008; Stewart et al., 2012). Wsm loci govern resistance to MDMV and SCMV (Jones et al., 2011) as well as JGMV and SrMV (Stewart et al., 2013b) when introgressed into the susceptible maize inbred line $\mathrm{Oh} 28$.

In Bangladesh, no line or landrace has been identified yet as a resistant one. So, screening of maize genotypes as a source of virus resistance might be a potential need. This research program has been conducted to screen maize genotypes carrying Wsm gene and resistant gene against MDMV and MCDV using SSR marker. Additionally, virus was introduced into all maize genotypes artificially from which infection percentage and area under disease progress curve (AUDPC) were calculated. Both results were compared to identify best genotype carrying resistant gene and giving functional resistance.

\section{Materials and Methods}

\section{Experimental site and plant materials}

Experiment was conducted in the net house, Department of Genetics and Plant Breeding, Bangladesh Agricultural University (BAU) and Biotechnology Laboratory of Biotechnology Division, Bangladesh Institute of Nuclear Agriculture (BINA). Nine maize genotypes (Uttaran, Duranta, BHM-5, BHM-7, BHM-9, V-92, H-981, pop corn and sweet corn) taken from Bangladesh
Agricultural Research Institute (BARI) were selected as experimental materials.

\section{Virus inoculation and scoring}

Virus stocks were incorporated into seeds (developed from $\mathrm{BC}_{1}-\mathrm{F}_{1}$ progeny of a backcross between $\mathrm{Pa} 405$ and Oh28) through vascular puncture inoculation (VPI) method (Stewart et al., 2013a). Seeds were received as a cordial gift from Stewart. Those seeds were planted and after growing, leaves with virus symptom were collected. The virus infected leaves were used to prepare inoculation sap which was artificially inoculated into experimental materials at 3-4 leaf stage by rubbing. Carborundum powder and buffer solution were added to the sap. Plants were inoculated at total of three times at two to three days intervals. Individual plants were scored as no symptoms (0), limited symptoms (1) and severe symptoms (2) at 7,10 and 14 days post-inoculation (dpi) with day 0 being the first inoculation date.

\section{Genomic DNA Isolation and Polymorphism Survey for Primer Selection}

DNA was extracted from the young leaves from 25 days old seedlings of each genotype using the Cetyl Trimethyl Ammonium Bromide (CTAB) mini-prep (modified) method. The quality of the isolated DNA in the protocol was sufficient for PCR analysis. Three sets of primer (Table 1) were used for screening: umc1300 for detection of Wsm loci (Ingvardsen et al., 2010), MDMVgen for detection of loci responsible against MDMV and MAHP35-MCDV-s for loci against MCDV (http://www.maizegbd.org). These markers were selected based on their potentiality for population discrimination which was determined by preliminary experiment with three sets of primers (data not shown).

\section{Table 1. List of SSR primer used for screening maize lines carrying desired loci}

\begin{tabular}{lllll}
\hline Name of primer & & \multicolumn{1}{c}{ Sequence } & GC $\%$ & Melting temperature $\left(\mathrm{Tm}^{\circ}\right)$ \\
\hline \multirow{2}{*}{ umc1300 } & Forward & ACCACCAGGTGTCCTTCCTT & 55 & 64.7 \\
& Reverse & GTTGCAGCAGACGAAGAA & 50 & 60.3 \\
\multirow{2}{*}{ MDMVgen } & Forward & CACCAATTAACCCTCACTAAAGGGAAA & 40.7 & 68.1 \\
& Reverse & TTTTTTGTCTCTCACCACGAAAC & 39.1 & 64.1 \\
\multirow{2}{*}{ MAHP35-MCDV-s $\mathrm{s}$ - Forward } & TGTTCCACGGAAGCGCCGA & 63.1 & 74.6 \\
& Reverse & CATTAAAACCGGACTGAGCGGTGGC & 56 & 74.9 \\
\hline
\end{tabular}

\section{PCR amplification profile}

PCR amplification reactions for each of the SSR markers were performed in a $10 \mu \mathrm{l}$ reaction volume containing $2 \mu \mathrm{l}$ genomic DNA, $1 \mu \mathrm{l}$ of $10 \mathrm{X}$ buffer, $0.8 \mu \mathrm{l}$ of $\mathrm{MgCl}_{2}, 2 \mu \mathrm{l}$ 0f dNTPs, $0.5 \mu \mathrm{l}$ of each forward and reverse primer, $0.2 \mu \mathrm{l}$ of Taq polymerase and $3 \mu \mathrm{l}$ of $\mathrm{ddH}_{2} \mathrm{O}$. PCR amplification was performed using a touchdown profile (Ingvardsen et al., 2010) designed for the annealing temperature $\left(\mathrm{T}_{\mathrm{a}}\right)$ of the primer pair: initial denaturation, followed by 12 cycles of $30 \mathrm{~s}$ at $94^{\circ} \mathrm{C}, 1$ min at $\mathrm{Ta}+12{ }^{\circ} \mathrm{C}$ and $1 \mathrm{~min}$ at $72{ }^{\circ} \mathrm{C}$ with a reduction of the annealing temperature of $10 \mathrm{C}$ at each cycle, followed by 30 cycles of s at $94{ }^{\circ} \mathrm{C}, 1 \mathrm{~min}$ at $\mathrm{Ta}$ and $1 \mathrm{~min}$ at 72 ${ }^{\circ} \mathrm{C}$, followed by a final extension.

\section{Data Analysis}

Scoring of virus symptoms had been used to calculate \% infection and AUDPC (Area Under Disease Progress Curve). Percent infection is the mean for three independent replications of each line. AUDPC was calculated from means of disease ratings for each line in each replicate using trapezoid method from the time of first disease scoring. The trapezoid method is the most common way to calculate AUDPC. It is performed by using a formula devised by Campbell and Madden in 1990 or by plotting a graph of percentage of infection against time and summing the trapezoids between time intervals (http://www.ehow.com/how12033613calculateaudpc.btml). The genotype with $100 \%$ infection would posses 14 score in AUDPC. 
Three types of primer evolved three different types of conclusion. The first primer, umc1300 was used to identify lines carrying Wsm loci. The lines responsible against MDMV and MCDV were screened using MDMVgen primer and MAHP35-MCDV-s primer, respectively. In all above cases only the presence and absence of band will be observed. Presence of band referred the genotype as resistant and absence of band indicated the genotype as susceptible.

\section{Results}

\section{Responses of maize genotypes to viruses}

In the experiment nine genotypes were inoculated with virus and scored for symptoms development at 7, 10 and 14 dpi (days post inoculation). The mean percentage infection and AUDPC for each line are shown in Table 2. A control was maintained for each genotype, but in Table 2 a representative one has been shown.

Table 2. Responses of different maize genotypes inoculated with virus

\begin{tabular}{cccc}
\hline $\begin{array}{c}\text { Sl. } \\
\text { No. }\end{array}$ & $\begin{array}{c}\text { Genotype } \\
\text { Name }\end{array}$ & \% Infection & $\begin{array}{c}\text { AUDPC (Area } \\
\text { Under Disease } \\
\text { Progress Curve) }\end{array}$ \\
\hline 1 & Pop corn & 66.67 & 9.700 \\
2 & BHM-9 & 88.83 & 12.995 \\
3 & BHM-7 & 33.33 & 4.840 \\
4 & BHM-5 & 60.00 & 9.000 \\
5 & V-92 & 22.17 & 3.160 \\
6 & Uttaran & 33.33 & 4.840 \\
7 & Duranta & 50.00 & 7.335 \\
8 & H-981 & 66.67 & 9.600 \\
9 & Sweet corn & 72.17 & 10.155 \\
10 & Control & 11.00 & 1.815 \\
\hline
\end{tabular}
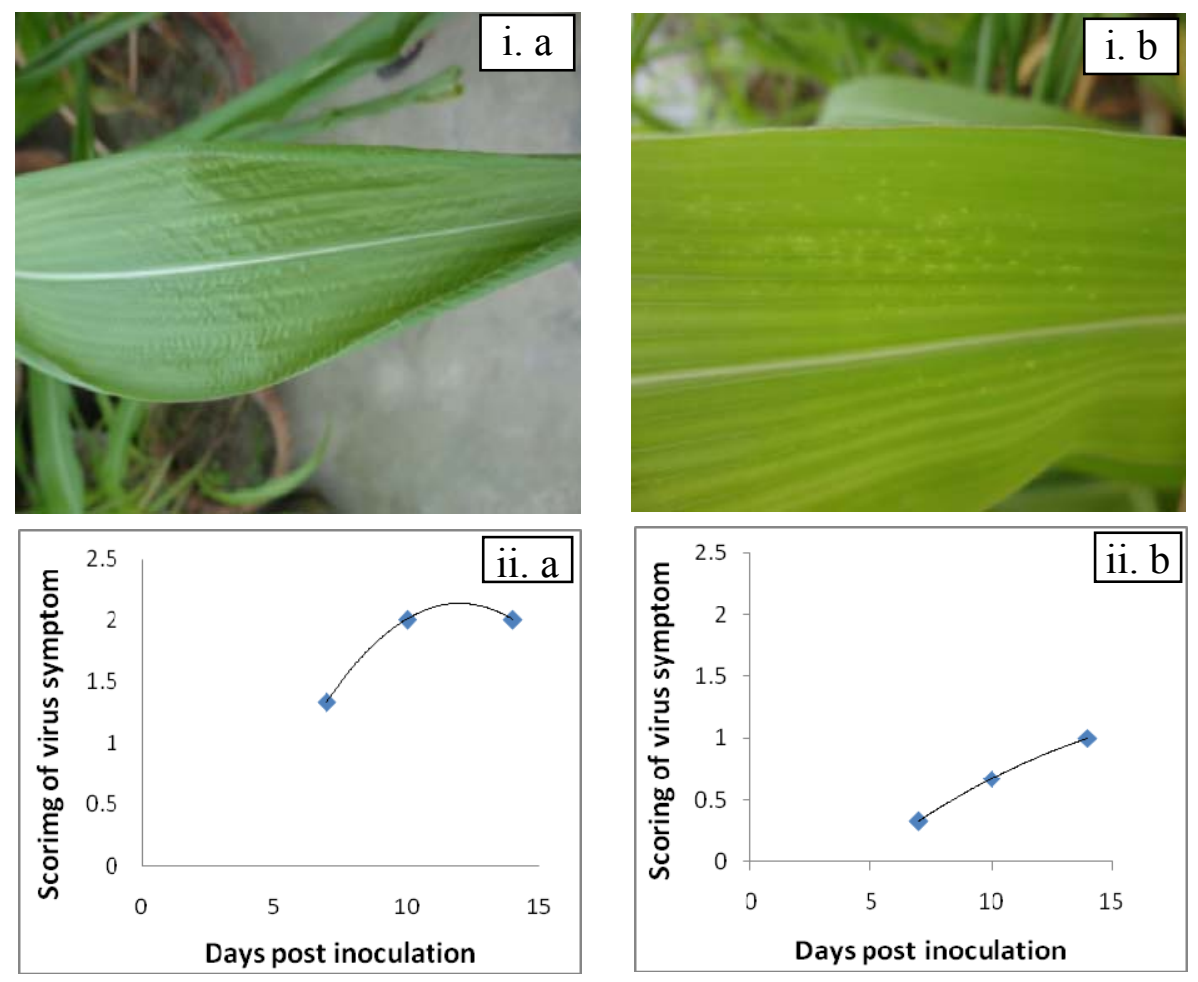

Fig. 1. Virus symptoms observed during scoring (i) and disease progress curve (ii) for genotype BHM-9 (a) and BHM-7 (b)

The highest infection percentage (88.88\%) was observed for BHM-9 having AUDPC value around 13 out of 14, followed by Sweet corn (72.17\%) with 10.155 AUDPC value (Table 2). In BHM-9, severe curling of leaves and disease progress curve indicated high susceptibility to potyvirus (Fig.1: i.a and ii.a). Followed by Pop corn and H-981 both had same infection rate $(66.67 \%)$ but value of AUDPC were slightly different $(9.7$ and 9.6 respectively) (Table 2). Pop corn and H-981 had common mosaic symptoms and mild curling (Figure not shown). BHM-5 had lower infection and symptom severity than BHM-9, BHM-7, Pop corn and Sweet Corn. Its recorded infection was $60 \%$ and AUDPC value was 9 (Table 2). Transparent long streak beside mid rib, mild curling and limited mosaic had been also scored for BHM-5 which gave a clear idea of disease progression (Figure and graph not shown). So, it might be moderately susceptible to virus. Duranta had almost similar type of symptoms of BHM- 5 but disease severity was lower than that. A $50 \%$ infection was observed in 7.335 for AUDPC (Table 2). Though it was less severe, the disease progress curve showed gradual increase in disease symptom (Graph not shown). Observing infection percentage Duranta might be considered as moderately resistant to virus. The disease severity is almost similar for Uttaran and BHM-7. Both had same infection rate $(33.33 \%)$ and same value for AUDPC (4.84) which indicated that their symptom severity was lower than other genotypes except V-92 (Table 2). Only light mosaic symptom was observed for BHM-7 which ultimately showed less disease severity (Fig1: i.b and ii.b). 
V-92 showed least disease severity than any other inoculated genotype. Only slight mosaic symptom was observed during scoring which results in lowest infection rate $(22.17 \%$ ) with the lowest AUDPC value of 3.16 (Table 2). Control (without virus inoculation) was maintained for each genotype, only one representative one is shown here. Theoretically, control (without virus inoculation) should not express any symptoms as there was no inoculation. But in this experiment, difference had been observed i.e. very slight curling was present (Figure not shown). This might be due to insect vector which transmitted virus from inoculated plant to control. As a result instead of $0 \%$ infection, $11 \%$ infection was observed with 1.815 value of AUDPC (Table 2).

\section{Molecular detection using SSR primer}

Three sets of primers were used to detect desired gene in the genotype. Detection of Wsm gene was carried out using umc1300 primer. Umc1300 is a universal primer which screened five genotypes out of nine showing clear bands at around $485 \mathrm{bp}$ which indicated presence of Wsm gene (Fig. 2). Genotype having Wsm gene were considered as resistant to potyviruses and genotype without Wsm loci were considered as susceptible. According to this BHM-7, BHM-5, Duranta, Uttaran and V-92 were found as resistant (Table 3).

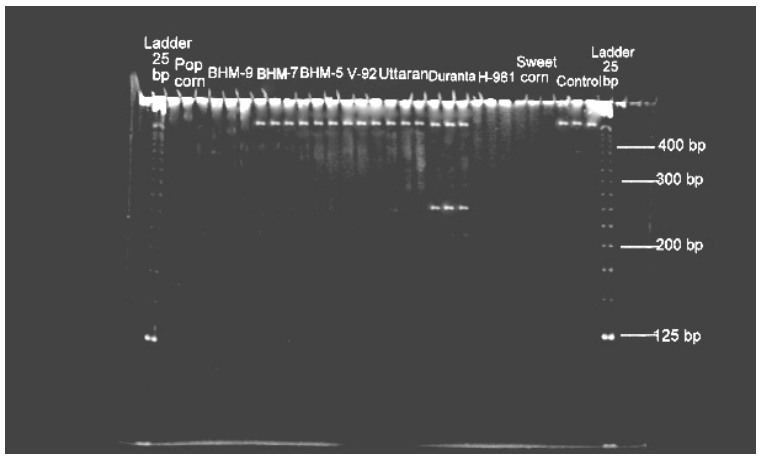

Fig. 2. Banding pattern of nine maize genotypes each with three replication using umc1300 primer confirming the presence of Wsm gene

Table 3. Resistance pattern of nine maize genotypes using three sets of markers

\begin{tabular}{|c|c|c|c|c|c|c|}
\hline \multirow[t]{2}{*}{ Genotypes } & \multicolumn{2}{|c|}{$\begin{array}{c}\text { Banding pattern confirming Wsm gene } \\
\text { against Potyvirus using } \\
\text { umc } 1300 \text { primer }\end{array}$} & \multicolumn{2}{|c|}{$\begin{array}{c}\text { Banding pattern against MDMV } \\
\text { using } \\
\text { MDMVgen primer }\end{array}$} & \multicolumn{2}{|c|}{$\begin{array}{l}\text { Banding pattern against } \\
\text { MCDV using } \\
\text { MAHP01-MCDV-s primer }\end{array}$} \\
\hline & $\begin{array}{c}\text { Presence } \\
(\mathrm{P})\end{array}$ & $\begin{array}{l}\text { Absence } \\
\text { (A) }\end{array}$ & $\begin{array}{c}\text { Presence } \\
\text { (P) }\end{array}$ & $\begin{array}{l}\text { Absence } \\
\text { (A) }\end{array}$ & $\begin{array}{c}\text { Presence } \\
\text { (P) }\end{array}$ & $\begin{array}{l}\text { Absence } \\
\text { (A) }\end{array}$ \\
\hline Popcorn & - & $\mathrm{A}$ & - & $\mathrm{A}$ & - & $\mathrm{A}$ \\
\hline ВНМ-9 & - & A & - & A & - & A \\
\hline ВНМ-7 & $\mathrm{P}$ & - & $\mathrm{P}$ & - & - & A \\
\hline ВНМ-5 & $\mathrm{P}$ & - & - & A & - & A \\
\hline V-92 & $\mathrm{P}$ & - & - & $\mathrm{A}$ & - & A \\
\hline Uttaran & $\mathrm{P}$ & - & - & A & - & A \\
\hline Duranta & $\mathrm{P}$ & - & - & A & - & A \\
\hline H-981 & - & A & - & A & - & A \\
\hline Sweet corn & - & A & - & $\mathrm{A}$ & - & A \\
\hline
\end{tabular}

MDMVgen primer was used for detection of genotype carrying loci responsible against MDMV which results in screening of a genotype showing clear band at around 125bp. As MDMV is a potyvirus, so the genotypes carrying Wsm gene should also govern resistance to this virus. But in molecular level, only one genotype (BHM7) out of five genotype carrying Wsm gene showed the desired band (Fig. 3) i.e. showing resistance against MDMV. So, remaining eight genotypes were considered as susceptible and only BHM-7 was as resistant.

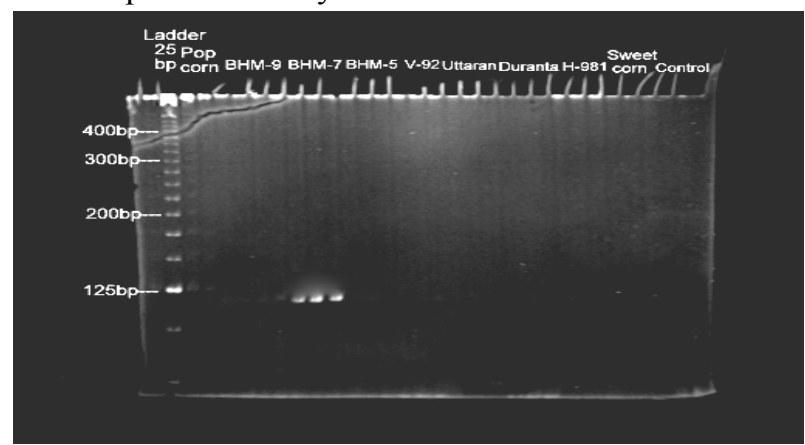

Fig. 3. Banding pattern of nine maize genotypes against MDMV using MDMVgen primer
No band was observed while MAHP01-MCDV-s primer was used to detect loci responsible against MCDV (Fig. 4). Many reasons could be responsible for failure in detection of gene responsible against MCDV. Further investigation is needed to find out cause or the way to detect the desired gene. From this finding, nine genotypes were considered as susceptible due to absence of band (Table 3 ).

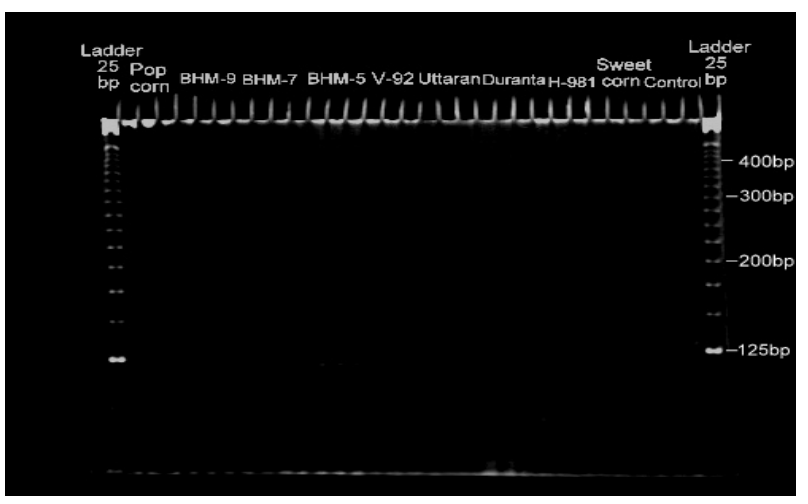

Fig. 4. Banding pattern of nine maize genotypes against MCDV using MAHP01-MCDV-s primer 


\section{Discussion}

Performance of maize genotypes after virus inoculation

Scoring on viral symptoms was performed at 7, 10 and 14 days after inoculation of virus. Based on this value, infection (\%) and AUDPC (Area Under Disease Progress Curve) were calculated (Table 2). High value of infection (\%) and AUDPC indicated susceptibility and low value indicated resistance. So, V-92 might be considered as highly resistant; Uttaran and BHM-7 as moderately resistant; Pop corn, H-981, Duranta and BHM-5 as moderately susceptible; Sweet corn and BHM-9 as highly susceptible.

Stewart et al. (2013a) inoculated virus to a number of genotypes and calculated \% infection and AUDPC at 0 $14 \mathrm{dpi}$ and 0-28 dpi. They found that the resistant genotype showed no infection $(0 \%)$ and the susceptible one showed $100 \%$ infection. Molecular work was also performed to assure the scoring results. Jones et al. (2011) also got almost similar results while calculating $\%$ infection and AUDPC from scoring after inoculation. The susceptible genotype showed $100 \%$ and $80 \%$ infection in field condition and green house, respectively; whereas the resistant one showed $0 \%$ infection in both environments. Wsm confer resistance in dosage dependent manner.

In current study, the identified resistant genotypes were expected to carry Wsm gene, whether it might be Wsm1 or Wsm2 or Wsm3. But this assumption is made only based on virus symptom expressed in genotypes which were artificially inoculated with virus. To make sure about resistance or presence of Wsm gene, study was extended to molecular level.

\section{Response of maize genotypes carrying Wsm gene}

Wsm is a novel QTL (Quantitative Trait Loci) governing resistance to almost all members of the genus Potyvirus. The resistance was governed by either Wsm1 or Wsm2 or Wsm3 or any interaction of these three loci. Wsm1 provides resistance to both MDMV and SCMV but Wsm2 and Wsm3 cannot confer resistance by themselves to either MDMV or SCMV, but enhance resistance to both (Jones et al., 2011). Again, in case of JGMV and SrMV, Wsm1 confers resistance in a dose dependent manner and Wsm2 and Wsm3 confer more resistance in combination with Wsm2 (Stewart et al., 2013b). In general, Wsm loci are mainly responsible for resistance against different potyviruses following different mechanisms.

Here, only five genotypes among eight i.e. BHM-7, BHM-5, Uttaran, Duranta and V-92 were found to carry Wsm gene (Fig. 2). That's why these five genotypes having Wsm gene should govern resistance to potyviruses. But, infection percentage and AUDPC value indicated that, only BHM-7, V-92 and Uttaran were performed as resistant against potyvirus (Table 2) and BHM-5 and Duranta were not actively resistant although they possessed the desired gene. The reason behind this might be the non functional role of Wsm1 rather Wsm2 and/or Wsm3 (Stewart et al., 2013a). Pop corn, BHM-9, H-981 and Sweet corn were lack of that locus as a result they performed as susceptible genotype according to infection \% and AUDPC value.

McMullen and Louie (1991) used to rub-inoculate greenhouse-grown maize plants with an isolate of WSMV and suggested the presence of multiple genes controlling resistance to WSMV using RFLP (Restriction fragment length polymorphism) marker which also demonstrated that one specific gene for resistance in $\mathrm{Pa} 405$ was also located on chromosome 6 of maize. Zhang et al. (2016) conducted an experiment on wheat to identify germplasm that might carry resistance gene different from Wsm2. Eight newly reported resistant lines were examined by allelic tests and five of them were further analyzed for the inheritance of WSMV resistance. A Wsm2 linked marker was also genotyped on populations developed which suggested that WSMV resistance in six lines among them was controlled by either Wsm2 or a gene very closely linked to Wsm2. Resistance in rest two lines was controlled by a gene different form, but linked to $\mathrm{Wsm} 2$.

In this experiment, specific loci (Wsm1 or Wsm2 or Wsm3) responsible for resistance could not be identified. But the clear band of $485 \mathrm{bp}$ for each replication of those five genotypes confirmed presence of desired Wsm gene. An additional band was observed for Duranta at around $250 \mathrm{bp}$, so author cannot exclude the possibility of presence of another allele/gene near or very closely linked to Wsm allele/gene. Further investigation is needed to find out the identity of that allele.

\section{Response of maize genotypes against MDMV and MCDV}

The performances of genotypes specifically against MDMV were also studied using separate primer sets. Similar type of experiment was also conducted by Jones et al. (2007) where 115 maize inbred lines were evaluated for resistance to MDMV and SCMV. $F_{2}$ populations were developed through crossing between resistant and susceptible lines which were scored for infection and symptom type. RFLP and SSR analyses were carried out using marker and data suggested that $M d m 1$ or closely linked genes on chromosome $6 \mathrm{~S}$ are associated with MDMV resistance in most germplasm, but that other loci also may affect resistance. In this case only one genotype out of nine (BHM-7) responded clearly (Fig. 3). But as MDMV is a member of genus Potyvirus, five genotypes carrying Wsm gene should also respond against MDMV. Presence of antagonistic relation might be the reason for which BHM-5, V-92, Uttaran and Duranta did not carry specific band responsible against MDMV. BHM-7 performed as resistant against MDMV (Table 3) due to presence of synergistic relation. 
In case of MCDV, no genotype showed band for resistance against this virus (Fig.4), that's why all genotypes were considered as susceptible (Table 3) to MCDV. Jones et al. (2004) conducted an experiment to identify quantitative trait loci (QTL) controlling resistance to MCDV. Progeny from a cross between resistant and susceptible inbred line subjected to virus inoculation and AUDPC scoring was done according to MCDV symptoms. In addition to that genotypic (using SSR marker) and phenotypic analyses were also done which identified two QTL on chromosome 3 and 10 governing equal resistance. One thing should be addressed in this study that MCDV is a member of the genus Waikavirus under the family Sequiviridae and Wsm gene is responsible for resistance against potyviruses. This may be one reason for non responding behavior of maize genotypes. Critical review is needed to get a clear idea on fact.

\section{Conclusion}

The experiment was conducted to screen locally available maize genotypes carrying Wsm gene using SSR marker and successfully identified five genotypes: BHM-7, BHM-5, V-92, Uttaran and Duranta among which BHM-7, V-92 and Uttaran showed functional resistance and BHM-5 and Duranta showed nonfunctional resistance considering \% infection and AUDPC value. BHM-9, H-981, Sweet corn and Popcorn were considered as susceptible genotype due to not having Wsm gene and high \% infection and AUDPC value. Only one genotype BHM-7 (BARI hybrid maize 7) also showed resistance specifically against MDMV as expected. No genotypes were found to govern resistance against MCDV. Further investigation is needed to find out the resistance mechanism of maize genotypes carrying Wsm gene.

\section{References}

Adams, M.J., Antoniw, J.F. and Fauquet, C.M. 2005. Molecular criteria for genus and species discrimination within the family Potyviridae. Archives of Virology, 150(3): 459-479. DOI: $10.1007 / \mathrm{s} 00705-004-0440-6$.

Ahmed, S. 2013. Study on genetic diversity in maize (Zea mays L.) inbred lines for the development of hybrids, PhD Thesis, Department of Genetics and Plant Breeding, Bangladesh Agricultural University, Bangladesh.

Balarabe, D.D., Adama, Y., Azmat, K. and Aisha, Z.M. 2014 Identification of virus isolates inducing mosaic of sugarcane in Makarfi Local Government Area of Kaduna State, Nigeria. African Journal of Biotechnology, 13(12): 1351-1357. DOI: 10.5897/AJB2013.13467 ISSN 1684 5315 .

Bradefute, O.E., Louie, R. and Knoke, J.K. 1972. Isometric virus like particles in maize with stunt symptoms. Phytopathology, 62: 748.

Dowswell, C.R., Paliwal, R.L. and Cantrell, R.P. 1996. Maize in the third World. Boulder, Colorado, Westview Press, USA.

Dujovny, G., Sasaya, T., Koganesawa, H., Usugi, T., Shohara, K. and Lenardon, S.L. 2000. Molecular characterizationof a new potyvirus infecting sunflower. Archives of Virology, 145(22): 49-58.

Fauquet, C.M., Mayo, M.A., Maniloff, J., Desselberger, U. and Ball, L.A. 2005. Virus Taxonomy: VIIIth Report of the
International Committee on Taxonomy of Viruses, Elsevier Academic Press, San Diego, CA, USA.

Ford, R.E., Tosic, M. and Shukla, D.D. 2004. Maize dwarf mosaic virus. $A A B$ Descriptions of Plant Viruses Online, pp. Description no. 341.

Gingery, R.E., Gordon, D.T., Nault, L.R. and Bradfute, O.E. 1981. Maize chlorotic dwarf virus. In E Kurstak, ed. Handbook of Plant Virus Infections and Comparative Diagnosis, North Holland Biomedical Press, Amsterdam, Elsevie, pp. 19-32.

Gong, F., Wu, X., Zhang, H., Chen, Y. and Wang, W. 2015. Making better maize plants for sustainable grain production in a changing climate. Frontiers in Plant Science, 6: 835. DOI: 10.3389/fpls.2015.00835

Haider, M.S., Afghan, S., Riaz, H., Tahir, M., Javed, M.A., Rashid, N. and Iqbal, J. 2011. Identification of two Sugarcane mosaic virus (SCMV) variants from naturally infected sugarcane crop in Pakistan. Pakistan Journal of Botany, 43(2): 11571162. http://www.ehow.com/how_12033613_calculateaudpc. html.http://www.maizegbd.org.

Ingvardsen, C.N., Yongzhong, X., Frei, U.K. and Lubberstedt, T. 2010. Genetic and physical fine mapping of Scmv2, a potyvirus resistance gene in maize. Theoretical and Applied Genetics, 120: 1621-1634. DOI 10.1007/s00122-0101281-1

Inoue-Nagata, A.K., Fonseca, M.E. and Resende, R.O. 2002. Pepper yellow mosaic virus, a new potyvirus in sweetpepper, Capsicum annuum. Archives of Virology, 147: 849-55. ISSN 0925-9864.

Jones, M.W., Redinbaugh, M.G., Anderson, R.J. and Louie, R. 2004. Identification of quantitative trait loci controlling resistance to maize chlorotic dwarf virus. Theoretical and Applied Genetics, 110: 48-57. DOI 10.1007/s00122-004-1757-y.

Jones, M., Boyd, E. and Redinbaugh, M. 2011. Responses of maize (Zea mays L.) near isogenic lines carrying Wsm1, Wsm2, and Wsm3 to three viruses in the Potyviridae. Theoretical and Applied Genetics, 123(5): 729-740.

Jones, M.W., Redinbaugh, M.G. and Louie, R. 2007. The Mdm1 locus and maize resistance to Maize dwarf mosaic virus. Plant Disease, 91: 185-190.

Klein, M., Harpaz, I., Greenberger, A. and Sela, I., 1973. A mosaic virus disease of maize and sorghum in Israel. Plant Disease Report, 57: 125-128.

Knoke, J.K. and Louie, R. 1981. Epiphytology of maize virus diseases. In D.T. Gordon, J.K. Knoke and G.E. Scott, ed. Virus and Virus-like Diseases of Maize in the United States. Southern Cooperative Series Bulletin, 247: 92-102.

Kuntze, L., Fuchs, E., Gruntzig, M., Schulz, B., Henning, U., Hohmann, F. and Melchinger, A.E. 1995. Evaluation of maize inbred lines for resistance to sugarcane mosaic virus (SCMV) and maize dwarf masaic virus (MDMV). Agronomie, 15: 463-467.

Lapierre, H. and Signoret, P.A., ed. 2004. Viruses and virus diseases of Poaceae (Gramineae), INRA Editions.

Larsen, R.C., Kaiser, W.J., Wyatt, S.D., Buxton-Druffel, K.L. and Berger, P.H. 2003. Characterization of a new potyvirus naturally infecting chickpea. Plant Disease, 87(13): 66-71.

McMullen, M.D. and Louie, R. 1991. Identification of a gene for resistance to wheat streak mosaic virus in maize. Phytopathology, 81: 624-627.

McMullen, M.D., Jones, M.W., Simcox, K.D. and Louie, R. 1994. 3 genetic loci control resistance to Wheat streak mosaic virus in the maize inbred Pa405. Molecular Plant-Microbe Interacteractions, 7: 708-712.

Mikel, M.A., D'Arcy, C.J., Rhodes, A.M. and Ford, R.E. 1984. Genetics of resistance of two dent corn inbreds to maize dwarf mosaic virus and transfer of resistance into sweet corn. Phytopathology, 74: 467-473.

Mohammadl, M.R. and Hajieghrari, B. 2009. Sugarcane mosaic virus: The causal agent of mosaic disease on sorghum (Sorghum bicolor L.) in Tehran province of Iran. African Journal of Biotechnology, 8(20): 5271-5274.

Moniruzzaman, M., Rahman, M.S., Karim, M.K. and Alam, Q.M. 2009. Agro-economic analysis of maize production in 
Bangladesh: A farm level study. Bangladesh Journal of Agricultural Researsh, 34: 15-24.

Moriones, E. and Luis-Arteaga, M. 2000. Viral Diseases. In Albajes, R., M.L. Gullino, J.C. Lenteren and Y. Elad, ed. Integrated Pest and Disease Management in Greenhouse Crops, Dordrecht, the Netherlands: Kluwer Academic Publishers, 23. Online at http://arts.bev.net/RoperLDavid/ interdisciplinarystudies.htm.

Paliwal, R.L., Granados. G., Lafitte. H.R. and Violic, A.D. 2000 Tropical maize improvement and production by FAO Plant Production and Protection, Series, No.28, Rome. pp. 363.

Pataky, J.K., Murphy, J.F. and D'Arcy, C.J. 1990. Resistance to maize dwarf mosaic virus, severity of symptoms, titer of virus, and yield of sweet corn. Plant Disease 74: 359-364.

Penrose, L.J. 1974. Identification of the cause of the red stripe disease in New South Wales (Australia) and its relationships to mosaic viruses in maize and sugarcane. Plant Disease Report, 58: 832-836.

Ranum, P., Pena-Rosas, J.P. and Garcia-Casal, M.N. 2014. Global maize production, utilization and consumption. Annals of the New York Academy of Sciences, 1312: 105-112.

Reddick, B.B., Habera, L.F. and Law, M.D. 1997. Nucleotide sequence and taxonomy of maize chlorotic dwarf virus within the family Sequiviridae. Journal of General Virology, 78: 1165-1174.

Redinbaugh, M.G. and Pratt, R.C. 2008. Virus Resistance. In S. Hake and J. Bennetzen, ed., Maize Handbook, $2^{\text {nd }}$ edition, Springer-Verlag, New York. pp. 255-270.

Roper, L.D. 2013. Crop production in the World and the United States. Online at: http://arts.bev.net/RoperLDavid/ interdisciplinarystudies.htm.

Shukla, D.D., Frenkel, M.J., McKern, N.M., Ward, C.W., Jilka, J., Tosic, M. and Ford, R.E. 1992. Present status of the sugarcane mosaic subgroup of potyviruses. Archives of Virology, 5: 363-373.
Stewart, L.R., Bouchard, R., Redinbaugh, M.G. and Meulia, T. 2012 Complete sequence and development of a full-length infectious clone of an Ohio isolate of Maize dwarf mosaic virus (MDMV). Virus Research, 165: 219-224.

Stewart, L.R., Haque, M.A., Jones, M. and Redinbaugh, M. 2013a. Response of maize (Zea mays L.) lines carrying Wsm1, Wsm2, and Wsm3 to the potyviruses Johnsongrass mosaic virus and Sorghum mosaic virus. Molecular Breeding, 31(2): 289-297.

Stewart, L.R., Paul, P., Qu, F., Redinbaugh, M.G., Miao, H., Todd, J.C. and Jones, M.W. 2013b. Wheat mosaic virus (WMoV), the causal agent of High Plains disease, is present in Ohio wheat fields. Plant Disease, 97: 1125.

Tosic, M., Benetti, M.P. and Conti, M. 1977. Studies on sugar cane mosaic virus (ScMV) isolates from northern and central Italy. Annals of Phytopathology, 13: 387-393.

Zambrano, J.L., Jones, M.W., Francis, D.M., Tomas, A. and Redinbaugh, M.G. 2014. Quantitative trait loci for resistance to Maize rayado fino virus. Molecular Breeding, 34: 989-996.

Zhang, X., Bai, G., Xu, R. and Zhang, G. 2016. Wheat streak mosaic virus resistance in eight wheat germplasm lines. Plant Breeding, 135: 26-30.

Zheng, L., Rodoni, B.C., Gibbs, M.J. and Gibbs, A.J. 2010. A novel pair of universal primers for the detection of potyvirus. Plant Pathology, 59: 211-220. DOI: 10.1111/j.13653059.2009.02201.x.

Zheng, L., Wayper, P.J., Gibbs, A.J., Fourment, M., Rodoni, B.C. and Gibbs, M.J. 2008. Accumulating variation at conserved sites in potyvirus genomes is driven by species discovery and affects degenerate primer design. PLOS ONE, 3(2): e1586. 